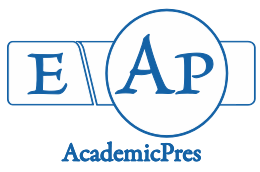

Falana MB and Nurudeen QO (2020)

Notulae Scientia Biologicae 12(2):208-221

DOI: $10.15835 / \mathrm{nsb} 12210699$

Research Article

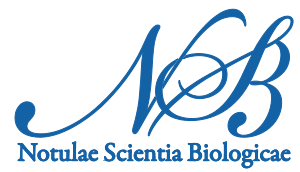

\title{
Evaluation of phytochemical constituents and in vitro antimicrobial activities of leaves extracts of Calotropis procera against certain human pathogens
}

\author{
Mansurat B. FALANA* Quadri O. NURUDEEN \\ Al-Hikmah University, Department of Biological Sciences, PMB 1601, Ilorin, \\ Nigeria;bolman4ever@yahoo.com (*correspondingauthor);quadriolaide@yahoo.com
}

\begin{abstract}
Calotropis procera, a well-known and commonly used plant in Nigeria to treat many infectious diseases, has been documented to possess constituents with proven antimicrobial potentials. The type of solvent used in herbal extraction determines the number of phytoconstituents extracted, therefore it was investigated the effect of some solvents selected based on polarity on the phytoconstituents and antimicrobial efficacy of leaves of $C$. procera. Phytochemical screening of extracts from leaves of $C$. procera obtained from five solvents (acetone, hexane, ethylactate, mixture "acetone, hexane, ethyl acetate 50/30/20 v/v/v" and sterile distilled water) was carried out. Disc diffusion assay, Minimum Inhibitory Concentration (MIC), Minimum Bactericidal Concentration (MBC) and Minimal Fungicidal Concentration (MFC) of the extracts were compared with those of commercial drugs (chloramphenicol, gentamicin and griseofulvin) against Candida albicans, S. aureus ATCC 25923 and E. coli ATCC 25922. Tannins, steroids, alkaloids, saponins, glycosides, terpenoids, proteins, flavonoids, coumarins and anthraquinones were detected in higher numbers in ethyl acetate and sterile distilled water extracts, while the least number of constituents were detected in hexane extracts. A dose- dependent broad spectrum of bacteriostatic/fungistatic and bactericidal activities was produced by the extracts against the tested pathogens. Wider inhibition zone $(19.80 \mathrm{~mm})$ was produced at $100 \mathrm{mg} / \mathrm{mL}$ concentration by the mixture of solvents and ethylacetate extract, respectively, while the lowest inhibition zone $(7.6 \mathrm{~mm})$ was produced by sterile distilled water extract at $25 \mathrm{mg} / \mathrm{mL}$. The present study provided plausible information to corroborate the medicinal value of the investigated plant, as claimed by herbal medicine users.
\end{abstract}

Keywords: antibacterial; antifungal; C. procera; phytochemicals; polarities

\section{Introduction}

C. procera (Ait) R. Br. Belongs to the Apocynaceae subfamily, formerly in the family Asclepiadaceae (Verma et al., 2010); is a flowering plant of about 2 meters high and $25 \mathrm{~cm}$ stem diameter (Little et al., 1974). All parts of the plant secrete white milky sap from cut (Aliyu, 2006). The plant, commonly known as 'giantmilkweed', 'calotrope', 'King's crown', 'kapok tree' is native to tropical Africa, Asia and now introduced to the Southern United States and Brazil (Tennet, 1993; Crothers et al., 1998). It is well-known in Nigeria as 
"bomubomu" (Southwestern Nigeria) and "Tumfatiya" (Northern Nigeria, where it is more common) (Chundattu et al., 2012).

Different parts of C. procera are used traditionally across many countries (Murti et al., 2010) to treat skin diseases like measles, muscular spasm, stomach ache, peptic ulcer, joint pain and constipation, etc. (Nenaah, 2013). Warmed leaves are used to relieve stomach, back and joint (Amit et al., 2012). Gwari communities of Northern Nigeria also use C. procera for topical treatment of ringworms (Kuta, 2008).

Also, antibacterial (Gajare et al., 2012) and antifungal (Kareem et al., 2008; Meena et al., 2010) properties of $C$. procera are well documented. A large number of secondary metabolites have been isolated from this plant (Ashwari, 2009; Morsy et al., 2016). Behl and Luthra (2002) also suggested the presence of active compounds such as alkaloids, steroids in C. procera extracts.

Despite the possibility of various solvents to extract numerous constituents from medicinal plants, it is imperative to elucidate the effectiveness of certain solvents based on their polarity in the extraction of constituents from the leaves of $C$. procera and to determine the varying antimicrobial potentials of these solvent extracts on selected pathogenic microorganisms. Therefore, these were the goals of the present investigation.

\section{Materials and Methods}

\section{Preparation and extraction of $C$. procera leaves}

The hereby research was conducted in Al-Hikmah University, Ilorin, Nigeria. Fresh leaves of actively growing $C$. procera plants were hand plucked before sunrise. The samples were identified and authenticated at the Herbarium of the Department of Plant Biology, University of Ilorin, Ilorin and a voucher specimen was deposited (UILH/001/1001). The leaves were thoroughly rinsed under running tap to remove dirt and subsequently rinsed with distilled water to remove all forms of contaminants from the running water. They were finally air-dried under the shade and reduced to a fine powder using an electric blender (Master Chef, Mode MC-BL 1980).

Extraction was made from the powdered leaves using five solvents (acetone, hexane, ethyl acetate, mixture "acetone, hexane, ethyl acetate 50/30/20 v/v/v/") at ratio $1: 10 \mathrm{w} / \mathrm{v}$ of plant material to solvent (Obeidat et al., 2012). The mixtures were left for 48 hours at room temperature with agitation at regular intervals (Asuzu and Onu, 1994), after which each extract was first filtered through a muslin cloth then the filtrate was further filtered through Whatman No. 1 filter paper (Farnsworth, 1996). The resulting filtrate was subsequently concentrated by evaporation to dryness using a rotary evaporator (Model RE Zhengzhou, Henan). The resulting crude extracts were collected, weighed and packed in sterile- labelled airtight McCartney bottles. They were stored at $4^{\circ} \mathrm{C}$ for further use.

\section{Preparation of different concentrations}

Concentrations of $100 \mathrm{mg} / \mathrm{mL}, 50 \mathrm{mg} / \mathrm{mL}$ and $25 \mathrm{mg} / \mathrm{mL}$ were prepared following the method described by Akujobi et al. (2004). A quantity ( $4 \mathrm{~g}$ ) of each crude extract was dissolved in $40 \mathrm{~mL}$ of $5 \%$ Dimethyl sulfide (5\% DMSO mixed with 95\% distilled water); this gave the stock solution of $100 \mathrm{mg} / \mathrm{ml}$ from which two-fold serial dilutions were made by transferring $5 \mathrm{~mL}$ from the stock solution into another tube containing $40 \mathrm{~mL}$ of $5 \%$ DMSO; this was then mixed thoroughly to obtain a concentration of $50 \mathrm{mg} / \mathrm{mL}$. Another $5 \mathrm{~mL}$ was transferred from this tube (containing $50 \mathrm{mg} / \mathrm{mL}$ solution) into a third tube containing 40 $\mathrm{mL}$ of $5 \% \mathrm{DMSO}$ and mixed thoroughly to give a concentration of $25 \mathrm{mg} / \mathrm{mL}$. These concentrations were used for further antimicrobial assays. 


\section{Testing for sterility of the extracts}

Each crude extract was tested for the absence of contaminants using the method described by Dalitha (2008); $1.0 \mathrm{~g}$ of each crude extract was serially diluted into $10 \mathrm{~mL}$ Mueller Hinton ((HiMedia) broth generate decreasing concentration up to $10^{-1}$, after which the tubes were incubated at $37^{\circ} \mathrm{C}$ for 24 hours. Clarity of the broth after 24 hours indicated sterility of the extracts.

\section{Test pathogenic strains}

Three pathogenic strains (Candida albicans, Escherichia coli ATCC 25920 and Staphylococcus aureus ATCC 25923) used in the present study were procured from Microbiology Laboratory of University of Ilorin Teaching Hospital, Ilorin. The bacterial strains were collected on nutrient agar slants, while the fungus was collected on Sabouraud Dextrose Agar slant. The strains were kept in the refrigerator at $4{ }^{\circ} \mathrm{C}$ and tested for viability by sub-culturing at $37^{\circ} \mathrm{C}$ for 24 hours and $48 \mathrm{~h}$ at $37^{\circ} \mathrm{C}$ respectively on their respective agar before any susceptibility testing.

\section{Preparation and standardization of inoculum}

Pure isolates of the bacteria and yeast were aseptically transferred to sterile test tubes containing about $6 \mathrm{ml}$ each of Nutrient Broth and Mueller-Hinton Broth (MHB). The approximate cell concentration in the broths was standardized by adjusting their McFarland density using a densitometer to achieve the final concentration of $1.5 \times 10^{8} \mathrm{cfu} / \mathrm{mL} \mathrm{CFU} / \mathrm{mL}$ of each test pathogen individually. These were incubated overnight at $37^{\circ} \mathrm{C}$ and for 48 hours at $30^{\circ} \mathrm{C}$ for bacteria and Candida respectively (Ochei and Kolhatkar, 2008).

\section{Determination of $M I C, M B C$ and $M F C$ of the crude extracts}

MIC of the crude extracts was determined using the microdilution method of CLSI (2008). Twofold serial dilutions of extracts were prepared directly in a microtiter plate containing Mueller Hinton broth (bacteria) and Sabouraud Dextrose broth (SDA) for (fungus) to obtain various concentrations $(100 \mathrm{mg} / \mathrm{mL}$, $50 \mathrm{mg} / \mathrm{mL}, 25 \mathrm{mg} / \mathrm{mL}, 12.5 \mathrm{mg} / \mathrm{mL}$ and $6.25 \mathrm{mg} / \mathrm{mL})$. The inoculum $(0.1 \mathrm{~mL}$ of the 18 hours broth culture) of each of the test organisms that have been adjusted to a turbidity equivalent to $0.5 \mathrm{McF}$ arland standard was introduced to each test tube containing the serially diluted extracts. The positive control, containing the reference drug was used as standard/control. The tubes were covered with cotton wool and incubated for 24 hours at $37^{\circ} \mathrm{C}$. The MIC considered as the tube with the lowest concentration of extract without growth after incubation was taken, and recorded (Moshi et al., 2006).

The MBC and MFC of the solvent extracts against the test pathogens were determined by aseptically sub-culturing with the aid of sterile wire loop from plates of the MIC that showed no growth (i.e. clear tube) of the pathogens on to sterile Muller Hinton agar plates and SDA agar plates for bacteria and yeast respectively. The plates were incubated at $37^{\circ} \mathrm{C}$ for 24 hours and $30^{\circ} \mathrm{C}$ for 48 hours respectively. The agar plates that showed no microbial growth after 24 hours and 48 hours respectively were taken as the MBC and MFC respectively.

The bactericidal or bacteriostatic effect of each solvent extract against the test pathogen was further determined by using the formula of Valgas et al. (2007):

Minimum Bactericidal Concentration / Minimum Inhibitory Concentration

or

Minimum Fungicidal Concentration / Minimum Inhibitory Concentration

If the ratio $\mathrm{MBC} / \mathrm{MIC}=1$ or 2 , the effect was considered bactericidal, while if the ratio $\mathrm{MBC} / \mathrm{MIC}=$ 4 or 16, the effect was considered bacteriostatic (Levinson, 2004; Benjamin et al., 2012). 


\section{Determination of antimicrobial susceptibility of the test pathogens}

Antimicrobial susceptibility test of all the test pathogens was done by Disc diffusion technique as previously described by Moshi et al. (2006). The test pathogens were inoculated onto Mueller Hinton and SDA for the disc diffusion assay. The discs (prepared from Whatman No. 1 filter paper, sterilized in an autoclave for $15 \mathrm{~min}$ at $15 \mathrm{lbs}$ pressure and allowed to cool) were pre-loaded with an equivalence of $20 \mu \mathrm{l}$ of the respective concentrations $(100 \mathrm{mg} / \mathrm{mL}, 50 \mathrm{mg} / \mathrm{mL}$ and $25 \mathrm{mg} / \mathrm{mL})$ of each solvent extract of leaves of $C$. procera. These were used as the antimicrobial discs and standard commercial discs (Chloramphenicol for Grampositive bacteria, Gentamicin for Gram-negative bacteria and Griseofulvin for the yeast) were used as positive controls. Negative control discs for organic solvents and distilled water extract were loaded with DMSO and distilled water respectively.

A maximum of three antimicrobial discs of each solvent extract was placed (equal distance from each other) onto plate inoculation with the test pathogen using sterile forceps. Positive and negative control discs were also placed on separate inoculated plates respectively. The treated plates were left on the bench for 1 hour for prior diffusion of the extracts from the discs into the agar medium then incubated for 24 hours at $37^{\circ} \mathrm{C}$ for bacteria and for 48 hours at $30^{\circ} \mathrm{C}$ for the yeast. The test was carried out for all investigated plant extracts and all test organisms in triplicate. Effectiveness of the solvent extracts was determined by calculating the means and standard deviations $( \pm S D)$ of the diameters of inhibition zone $(\mathrm{mm})$, measured as clear zones around the discs. The negative control (DMSO and distilled water) revealed no activity.

\section{The percentage yield of the solvents after extraction}

Extraction yields of $200 \mathrm{~g}$ of dry raw powder of leaves of $C$. procera using different solvents were calculated using the formula of Ellof (2004).

Percentage yield $(\%)=$ Dry weight of extract $\times 100 /$ Dry weight of plant material

\section{Phytochemical screening}

The secondary metabolites tested in the five solvent extracts of leaves of $C$. procera were tannins, steroids, alkaloids, saponins, glycosides, terpenoids, proteins, flavonoids, coumarins and anthraquinones. The method described by Harborne (1984) was adopted.

\section{Statistical analysis}

The in vitro experiments were done in triplicates and mean values of each triplicate results were presented.

\section{Results}

\section{The percentage yield of the solvents after extraction}

Extraction yields of $200 \mathrm{~g}$ of dry raw powder of leaves of $C$. procera using different solvents are presented in Table 1. The obtained results indicated that the highest yield (14.6\%) was obtained from acetone extract, while the least yield ( $4.6 \%$ ) was obtained from distilled water extract.

\section{Phytochemical compound present in the solvent extracts}

Nine phytoconstituents were detected out of the ten constituents (tannins, steroids, alkaloids, saponins, glycosides, terpenoids, proteins, flavonoids, coumarins and anthraquinones) screened in all the solvent extracts of leaves of $C$. procera (Table 2). The highest number (eight out of the ten screened constituents) of secondary metabolites were detected in ethyl acetate and distilled water extracts, seven constituents were detected in acetone extracts, while the least number (six) of secondary metabolites were detected in hexane extracts. 
Steroids, alkaloids and saponins were present in all the solvent extracts tested, while coumarins were absent in all the solvent extracts.

Table 1. Percentage yield from different solvent extracts of $C$. procera leaves

\begin{tabular}{|c|c|c|}
\hline Solvent & Yield from dry raw powder $(\mathrm{g})$ & Yield $(\%)$ \\
\hline Acetone & 29.2 & 14.6 \\
\hline Hexane & 20.3 & 10.15 \\
\hline Ethyl acetate & 14.8 & 7.4 \\
\hline Distilled water & 12.4 & 4.6 \\
\hline
\end{tabular}

Table 2. Distribution of phytoconstituents from different solvent extracts of $C$. procera leaves

\begin{tabular}{|c|c|c|c|c|c|}
\hline Constituents & Acetone & Hexane & Ethyl acetate & Mixture & Distilled water \\
\hline Tannins & + & + & + & + & - \\
\hline Steroids & + & + & + & + & + \\
\hline Alkaloids & + & + & + & + & + \\
\hline Saponin & + & + & + & + & + \\
\hline Glycosides & - & - & - & - & + \\
\hline Terpenoid & + & + & + & - & + \\
\hline Protein & + & - & + & + & + \\
\hline Flavonoid & + & + & + & + & + \\
\hline Anthraquinones & - & - & + & - & - \\
\hline Coumarins & - & - & - & & + \\
\hline
\end{tabular}

Key: + (Present), - (Absent)

Diameters of inhibition zones of solvent extracts against the pathogens at different concentrations

The result of the in vitro disc diffusion assay showed that all the solvent extracts used in the study exhibited a varying degree of concentration-dependent activities against all tested pathogenic microorganisms (Figure 1, 2 and 3). At $100 \mathrm{mg} / \mathrm{mL}$ concentration (Figure 1), the widest inhibition zone (19.80 mm) was produced by the mixture of solvents and ethyl acetate extract, respectively, against $E$. coli, while the lowest inhibition zone $(8.12 \mathrm{~mm})$ was produced by distilled water extract against $S$. aureus. Similarly, at $50 \mathrm{mg} / \mathrm{mL}$ tested concentrations (Figure 2), the widest inhibition zone $(18.00 \mathrm{~mm}$ ) was produced by the mixture of solvents extract against $E$. coli, while the lowest inhibition zone $(8.10 \mathrm{~mm})$ was produced by distilled water extract against $S$. aureus. However, at $25 \mathrm{mg} / \mathrm{mL}$ concentration (Figure 3), the widest inhibition zone (18.42 $\mathrm{mm}$ ) was produced by the mixture of solvents extract against $E$. coli, while the lowest inhibition zone (8.00 $\mathrm{mm}$ ) was produced by distilled water extract against $S$. aureus.

\section{Diameters of inhibition zones of the controls against the pathogens}

DMSO and distilled water showed no activity against the tested pathogens, while the commercial drugs tested produced activities ranging from $25 \mathrm{~mm}-30 \mathrm{~mm}$ (Figure 4).

$M I C$ and $M B C / M F C$ values of the solvent extracts against the pathogens at $100 \mathrm{mg} / \mathrm{mL}$

Varying MIC values were obtained for the solvent extracts against the test pathogens (Table 3). The range of MIC against the pathogens was between $6.25 \mu \mathrm{g} / \mathrm{mL}$ to $100.00 \mu \mathrm{g} / \mathrm{mL}$. No MIC was obtained by hexane extract on $S$. aureus and none was obtained by distilled water extract against $E$. coli. Generally, the MBC range for all solvent extracts investigated was from $12.50 \mu \mathrm{g} / \mathrm{mL}$ to $100.00 \mu \mathrm{g} / \mathrm{mL}$. 
Falana MB and Nurudeen QO (2020). Not Sci Biol 12(2):208-221

Table 3. MIC and MBC/MFC of $100 \mathrm{mg} / \mathrm{mL}$ concentration of the solvent extracts of $C$. procera leaves, against specific pathogens

\begin{tabular}{|c|c|c|c|c|c|c|}
\hline \multirow{3}{*}{ Solvents } & \multicolumn{3}{|c|}{ MIC $(\mu \mathrm{g} / \mathrm{mL})$} & \multicolumn{3}{c|}{ MBC/MFC } \\
\cline { 2 - 7 } & E. coli & S. aureus & & E. coli & S. aureus & \\
& ATCC & ATCC & C. albicans & ATCC & ATCC & C. albicans \\
& 25922 & 25923 & & 25922 & 25923 & \\
\hline Acetone & 12.50 & 50.00 & 12.50 & 50.50 & 100.00 & 50.00 \\
\hline Hexane & 12.50 & 6.25 & 12.50 & 50.00 & 12.5 & 25.00 \\
\hline Ethyl acetate & 12.50 & 12.50 & 25.00 & 25.50 & 25.50 & 50.00 \\
\hline Mixture & 6.25 & 12.50 & 25.00 & 12.50 & 25.00 & 50.50 \\
\hline Distilled water & - & - & - & - & - & - \\
\hline
\end{tabular}

Key: (-) no antimicrobial activity

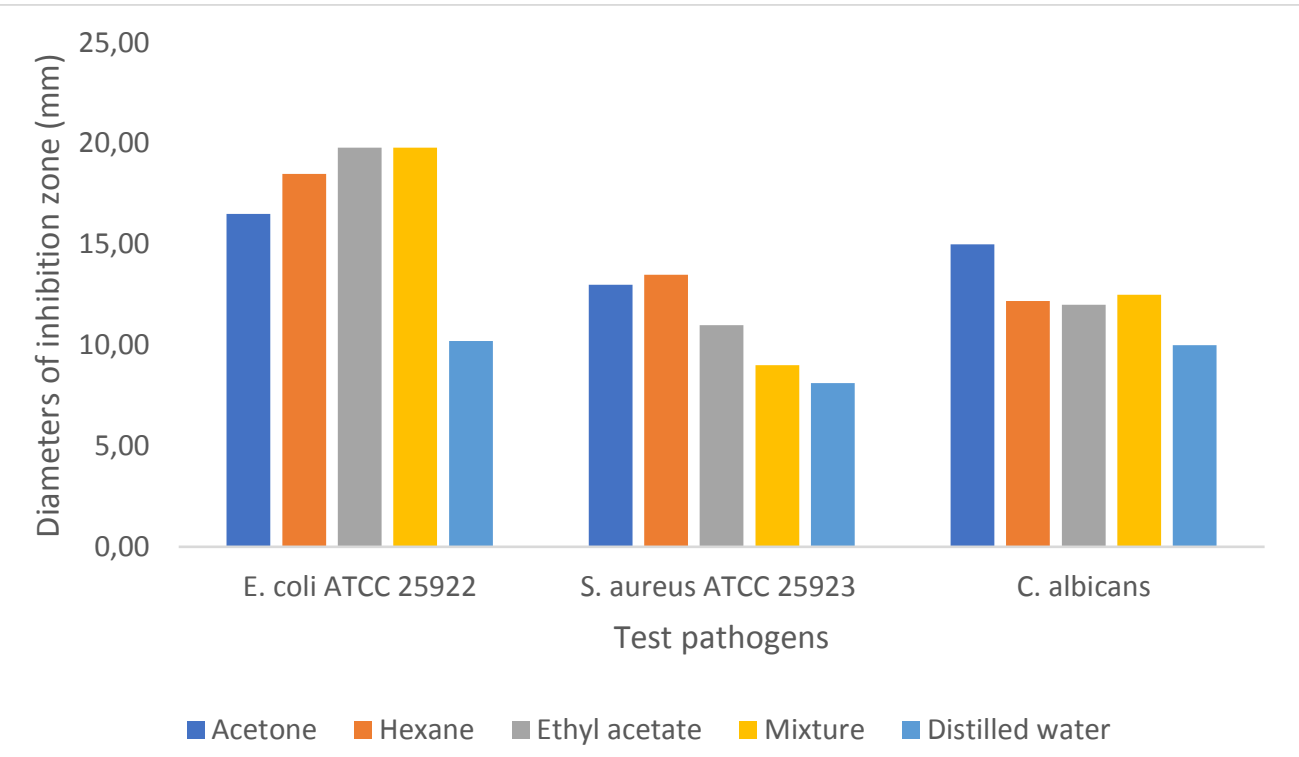

Figure 1. Diameters of inhibition zones of $C$. procera extracts at a concentration of $100 \mathrm{mg} / \mathrm{mL}$ against the test pathogens

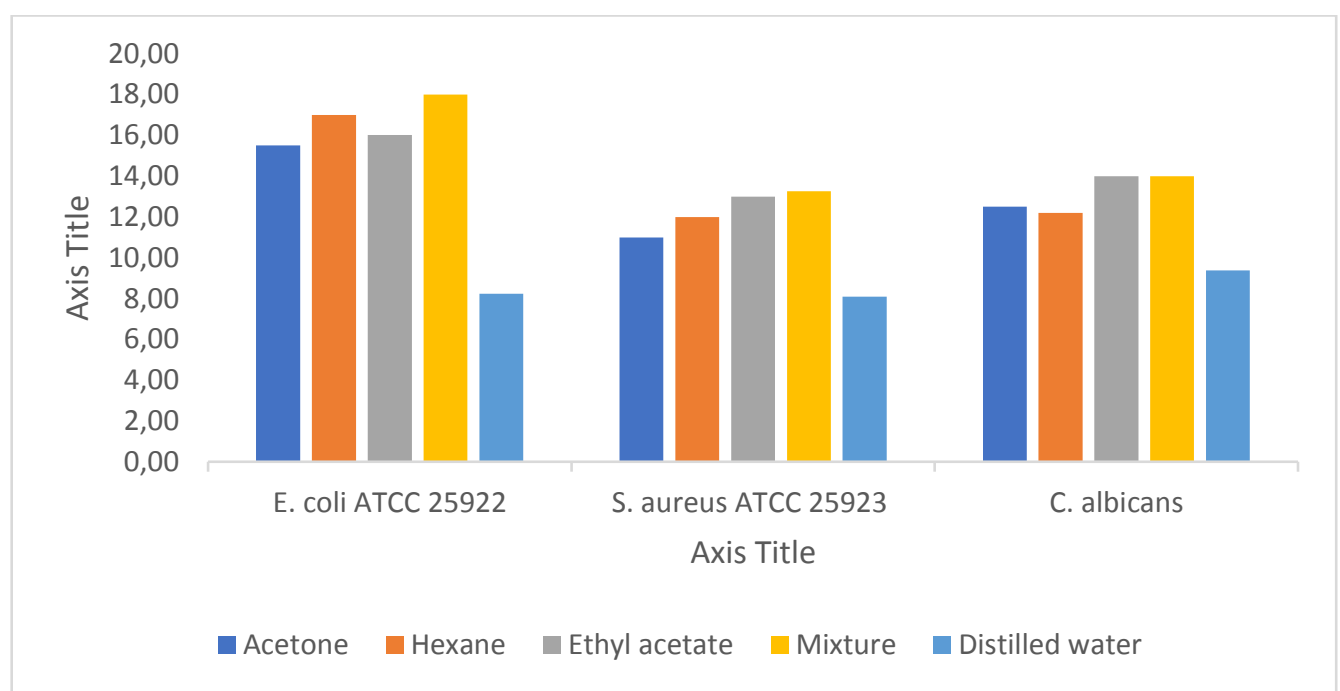

Figure 2. Diameters of inhibition zones of $C$. procera extracts at a concentration of $50 \mathrm{mg} / \mathrm{mL}$ against the test pathogens 


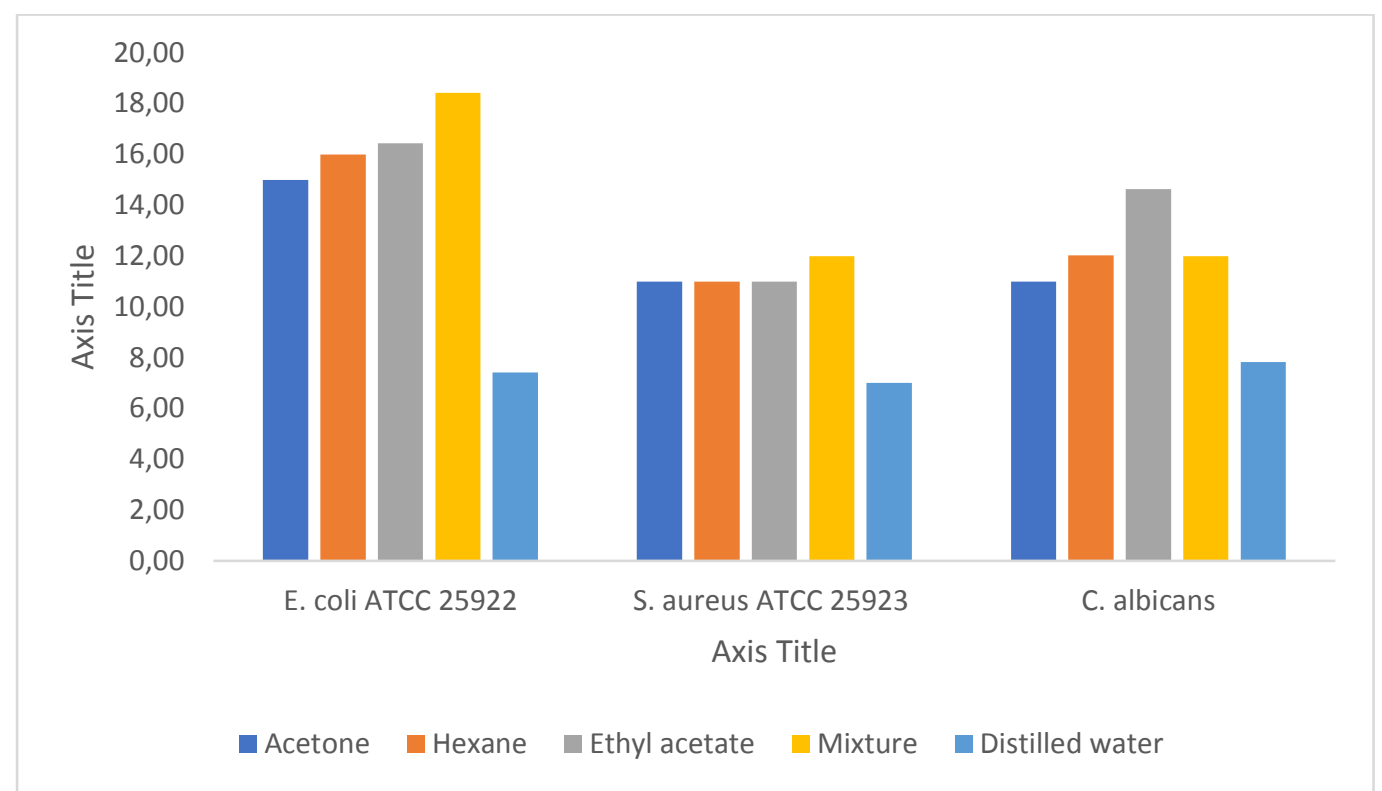

Figure 3. Diameters of inhibition zones of $C$. procera extracts at a concentration of $25 \mathrm{mg} / \mathrm{mL}$ against the test pathogens

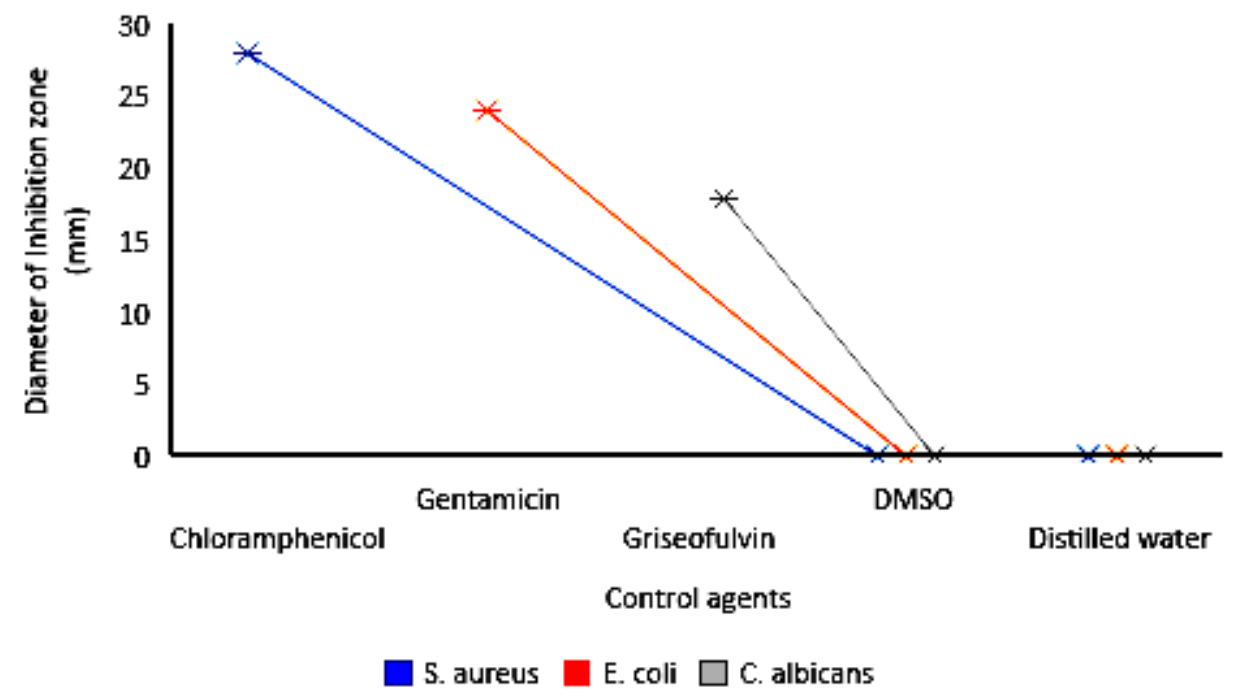

Figure 4. Diameters of inhibition zones of control agents against the test pathogens

\section{$M I C$ and $M B C / M F C$ values of the solvent extract against the pathogens at $50 \mathrm{mg} / \mathrm{mL}$}

Table 4 shows the range of MIC at $50 \mathrm{mg} / \mathrm{mL}$ against the test pathogens. The value range of MIC against the pathogens was between $6.25 \mu \mathrm{g} / \mathrm{mL}$ to $100.00 \mu \mathrm{g} / \mathrm{mL}$. Generally, the MBC range for all the solvent extracts was from $12.50 \mu \mathrm{g} / \mathrm{mL}$ to $100.00 \mu \mathrm{g} / \mathrm{mL}$.

\section{$M I C$ and $M B C / M F C$ values of the solvent extracts against the pathogens at $25 \mathrm{mg} / \mathrm{mL}$}

Table 5 shows the range of MIC at $50 \mathrm{mg} / \mathrm{mL}$ concentration against the test pathogens. The MIC values obtained against the test pathogens ranged between $6.25 \mu \mathrm{g} / \mathrm{mL}$ to $100.00 \mu \mathrm{g} / \mathrm{mL}$. No MIC was obtained for distilled water extract against all the test pathogens. Generally, the $\mathrm{MBC}$ range for all the solvent extracts was from $12.50 \mu \mathrm{g} / \mathrm{mL}$ to $100.00 \mu \mathrm{g} / \mathrm{mL}$. 
Table 4. MIC and MBC/MFC of $50 \mathrm{mg} / \mathrm{mL}$ concentration of the solvent extracts of $C$. procera leaves, against specific pathogens

\begin{tabular}{|c|c|c|c|c|c|c|}
\hline \multirow{3}{*}{ Solvents } & \multicolumn{3}{|c|}{ MIC $(\mu \mathrm{g} / \mathrm{mL})$} & \multicolumn{3}{c|}{ MBC/MFC } \\
\cline { 2 - 7 } & E. coli & S. aureus & & E. coli & S. aureus & \\
& ATCC & ATCC & C. albicans & ATCC & ATCC & C. albicans \\
& 25922 & 25923 & & 25922 & 25923 & \\
\hline Acetone & 12.50 & 50.00 & 50.0 & 50.50 & 100.00 & 50.00 \\
\hline Hexane & 12.50 & 100.00 & 50.00 & 50.00 & 100.00 & 50.00 \\
\hline Ethyl acetate & 12.50 & 25.50 & 25.00 & 25.50 & 25.50 & 50.00 \\
\hline Mixture & 6.25 & 25.50 & 25.00 & 12.50 & 25.00 & 50.00 \\
\hline Distilled water & 50.00 & 100.00 & 100.000 & 50.00 & 100.00 & 100.00 \\
\hline
\end{tabular}

Table 5. MIC and MBC/MFC of $25 \mathrm{mg} / \mathrm{mL}$ concentration of leaves of C. procera leaves, against specific pathogens

\begin{tabular}{|c|c|c|c|c|c|c|}
\hline \multirow{3}{*}{ Solvents } & \multicolumn{3}{|c|}{ MIC $(\mu \mathrm{g} / \mathrm{mL})$} & \multicolumn{3}{c|}{ MBC/MFC } \\
\cline { 2 - 7 } & E. coli & S. aureus & & E. coli & S. aureus & \\
& ATCC & ATCC & C. albicans & ATCC & ATCC \\
& 25922 & 25923 & & 25922 & C. albicans \\
& 50.00 & 50.00 & 100.00 & 50.00 & 100.00 & 100.00 \\
\hline Acetone & 25.50 & 100.00 & 100.00 & 50.00 & 10.0 & 100.00 \\
\hline Hexane & 12.50 & 25.00 & 50.00 & 25.50 & 25.00 & 50.00 \\
\hline Ethyl acetate & 6.25 & 25.00 & 50.00 & 12.50 & 25.00 & 50.00 \\
\hline Mixture & - & - & - & - & - & - \\
\hline Distilled water & - & - & & & \\
\hline
\end{tabular}

Key: (-) no antimicrobial activity

\section{Effects of bactericidal/fungicidal and bacteriostatic/fungistatic activities of the solvent extracts}

The ratio MBC/MIC (Figure 5, 6 and 7) of the solvent extracts at all the tested concentrations showed a bactericidal/fungicidal effect at $100 \mathrm{mg} / \mathrm{mL}$ of acetone (against E. coli and C. albicans) and hexane (against E. coli) and the bacteriostatic and fungistatic effects by other solvent extracts against other tested pathogens (Figure 5). However, bactericidal effect was given by $50 \mathrm{mg} / \mathrm{mL}$ of acetone and hexane, respectively, against $E$. coli, while bacteriostatic and fungistatic effect was given by other solvents against other test pathogens (Figure 6). At $25 \mathrm{mg} / \mathrm{mL}$ concentration, bacteriostatic and fungistatic effect was given by all the solvent extracts all the test pathogens (Figure 7).

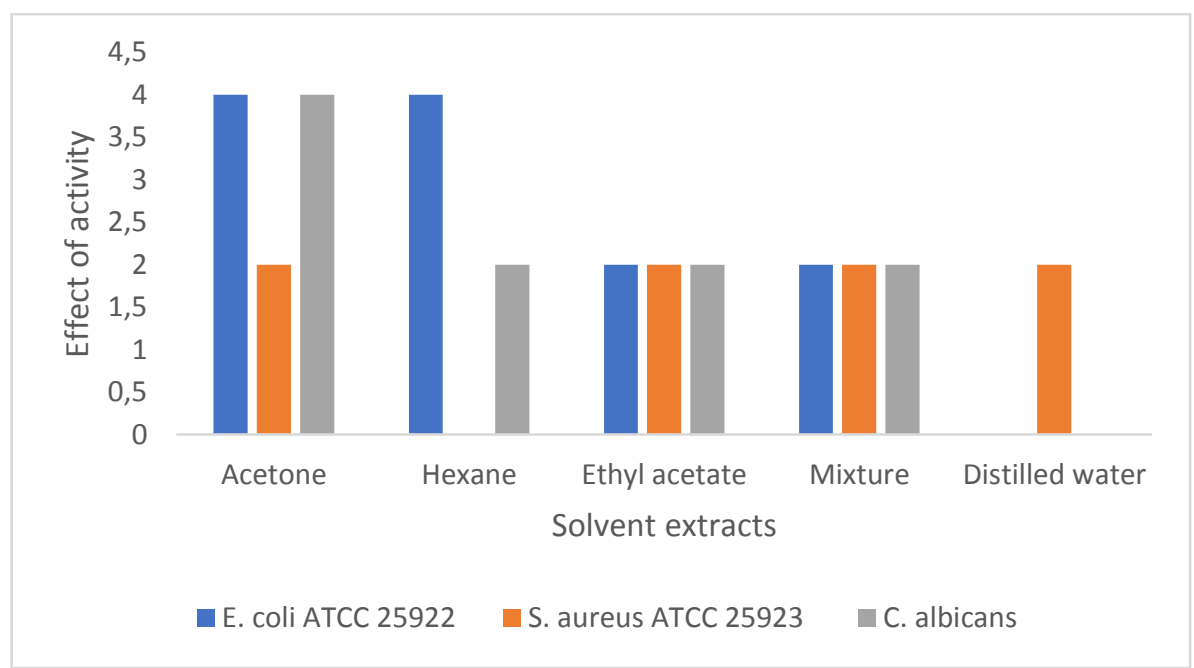

Figure 5. The ratio of $\mathrm{MBC} / \mathrm{MIC}$ of each solvent extract at $100 \mathrm{mg} / \mathrm{mL}$ concentration 


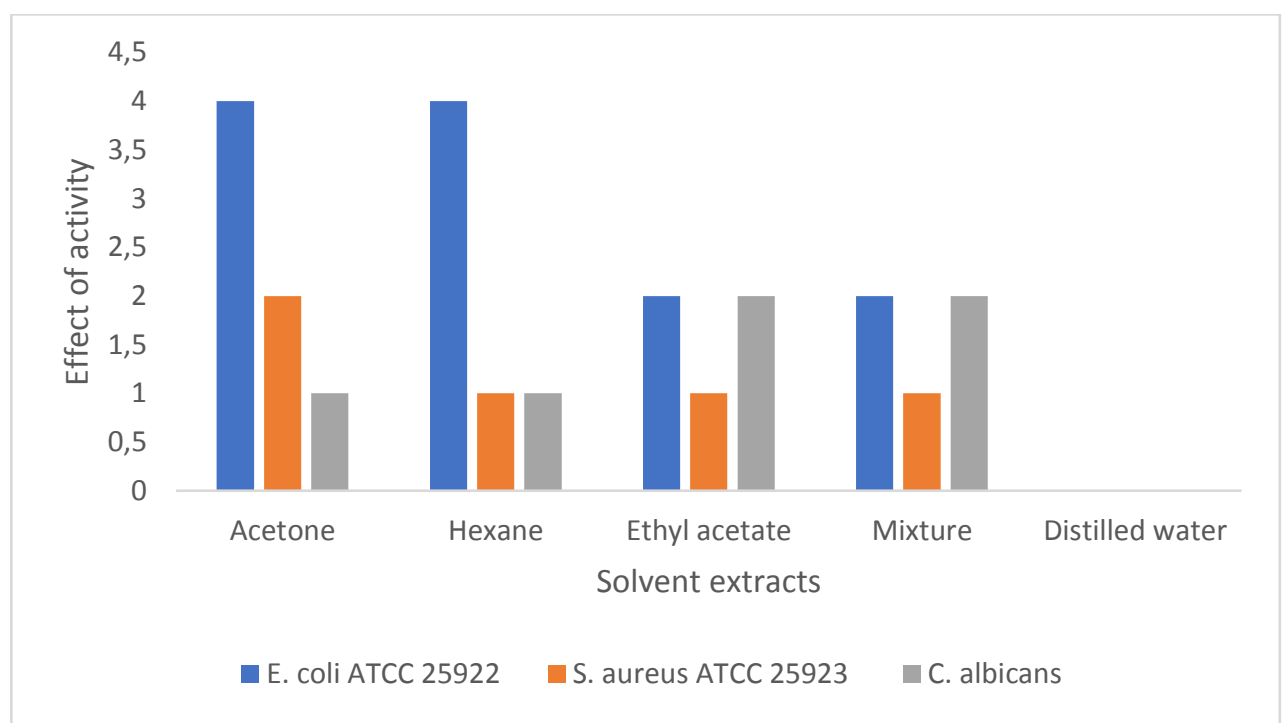

Figure 6. The ratio of MBC/ MIC of each solvent extract at $50 \mathrm{mg} / \mathrm{mL}$ concentration

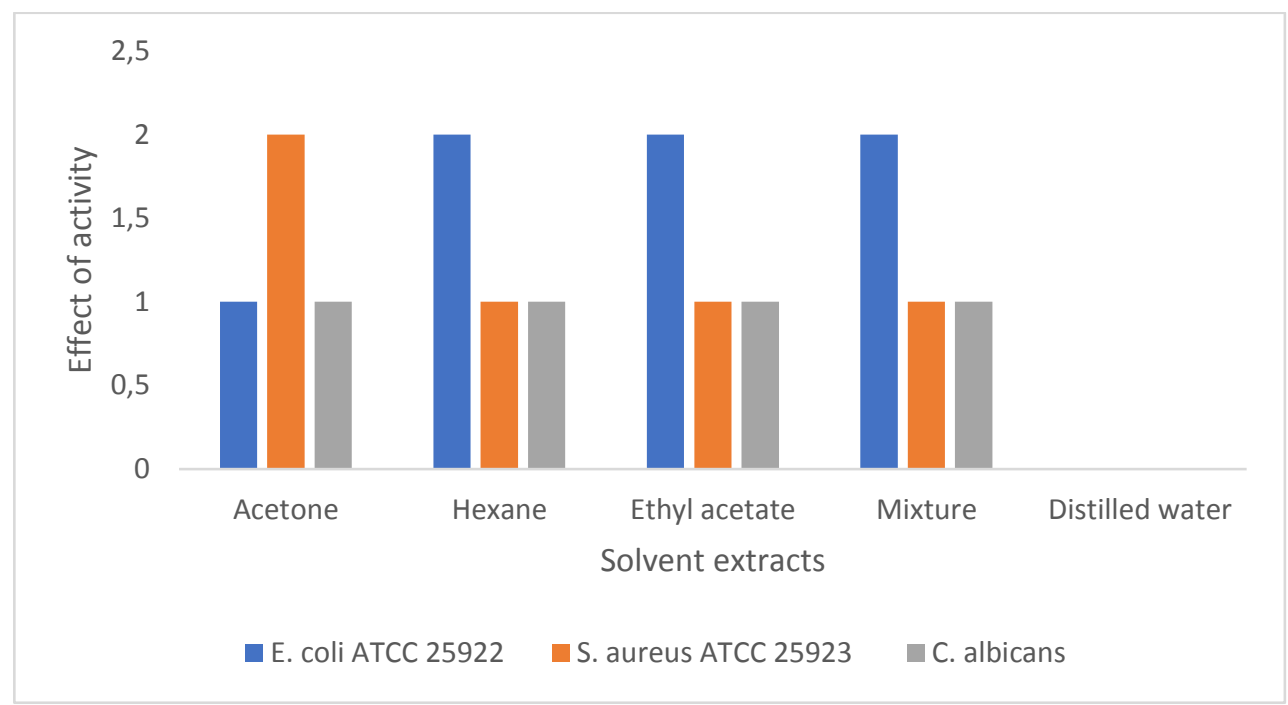

Figure 7. The ratio of $\mathrm{MBC} / \mathrm{MIC}$ of each solvent extract at $100 \mathrm{mg} / \mathrm{mL}$ concentration

\section{Discussion}

Plants which are regarded as medicinal are known to be rich in a wide variety of secondary metabolites such as tannins, alkaloids, phenolic compounds and flavonoids. The efficacy of these metabolites has been tested in several in vitro antimicrobial studies (Djeussi et al., 2013). In the light of the vast traditional use of leaves of $C$. procera and the scientific evidence of the presence of numerous secondary metabolites in the leaves of this plant, the hereby study was aimed at the use of solvents of varying polarities to maximally extract abundant secondary metabolites from the leaves of $C$. procera, and to test for the antimicrobial efficacy of the extracts against pathogenic organisms which are frequently associated with common infectious diseases.

Results of the present study show the presence of several of secondary metabolites including tannins, steroids, alkaloids, saponins, glycosides, terpenoids, proteins, flavonoids and anthraquinones in the solvent extracts of the studied plant. In agreement with the present results is the report of Silva (2010), who stated that C. procera is well known for its ability to produce several biologically active compounds. Numerous medicinal 
plants have equally been reported to harbor secondary metabolites including tannins, alkaloids, flavonoids and phenolic compounds (Duraipandiyan et al., 2006). The presence of such an impressive number of metabolites as obtained in the current investigation depicts that the leaves of $C$. procera can be used medicinally in the management of ailments caused by pathogenic microorganisms. To buttress this statement is the widely observed and accepted reports that medicinal values of plants is due to the bioactive phytocomponents present in them, that dissolve in different solvent systems (Cowan, 1999).

The presence of tannins only in the alcoholic extracts, but not in the sterile distilled water extracts, may account for the greater antimicrobial efficacy of the alcoholic extracts observed during the in vitro assay compared with sterile distilled water extract. A similar observation has been reported by Van Der Watt and Pretorius (2001) on the antibacterial potential of tannins; according to that report, tannins were able to react with proteins to form stable water-soluble compounds, thereby damaging the cell membrane of bacteria, thus lysing them. The presence of alkaloid and flavonoid in all the solvent extracts may also be responsible for their antimicrobial activities. The result is in line with the reports of some authors on the antibacterial activities of alkaloids and flavonoids from C. procera (Yesmin et al., 2008).

In general, all the solvent extracts of leaves of $C$. procera showed broad-spectrum antimicrobial activities by producing varying degrees of concentration-dependent inhibition zones against the tested organisms. Various reports have also confirmed that extracts of plants inhibit the growth of various microorganisms at different concentrations (Osadebe and Ukwueze, 2004; Ogueke et al., 2007). Despite the diameters of inhibition zones produced by the solvent extracts (alcoholic and distilled water extracts) against the test pathogens, these amounts were quite inimitable and low, compared to what was produced by the standard drugs of choice against the test pathogens. This may be due partly to the presence of purified compounds in standardized amounts in the standard antibiotics (Gatsing et al., 2010).

Minimum Inhibitory Concentration refers to the lowest concentration of an antimicrobial agent that prevents the growth of a pathogen. High values of MIC are an indication of limited antibacterial efficacy. The present study recorded varying low MIC values among the solvent extracts of $C$. procera against the test pathogens, supporting the antimicrobial activities observed among the solvent extracts against the test pathogens. The results are in line with reports by various researchers that MIC of plants is another important tool in determining the antimicrobial potentials of plants (Gurudeeban et al., 2010; Pavithra et al., 2010).

The acetone and hexane extracts displayed bactericidal activities at $100 \mathrm{mg} / \mathrm{mL}$ concentration against Gram-negative organism (E. coli), but displayed bactriostatic/fungistatic against other test organisms. In similarity to the susceptibility of the tested bacteria is the report of Ahmadizadeh et al. (2018), which also described the susceptibility of $E$. coli and $S$. aureus to other medicinal plants such as $A$. vulgaris. Of further relevance is the report of Yesmin et al. (2008) on the effectiveness of ethanol and water extracts of $C$. procera against both the Gram-positive and Gram-negative bacterial strains (Yesmin et al., 2008). Interestingly too, the report of Farouk et al. (2016) stated that the activity of ethyl alcohol extract of leaves of $C$. procera showed activity against both Pseudomonas aeruginosa ATCC 27853 and Candida albicans ATCC 10231 and such data corroborates the observed fungistatic activity of ethyl acetate extract (at $50 \mathrm{mg} / \mathrm{mL}$ and $25 \mathrm{mg} / \mathrm{mL}$ concentrations) in the present study.

The bactericidal and bacteriostatic/fungistatic activities of the studied solvent extracts may mean that the extracts were able to target the cell wall, disrupt the outer membranes and break the thick peptidoglycan layer for permeability into the bacterial cells, hence, are potent antimicrobial compounds. This is in agreement with individual reports by Cowan (1999) and Hooper (2001), where the mechanisms of actions of antimicrobial agents include targeting of cell wall synthesis, protein synthesis, RNA synthesis, DNA synthesis and intermediary metabolism.

However, the study showed that Gram-negative bacteria (E. coli) were more susceptible to the extracts than the Gram-positive bacteria (S. aureus). The dissimilarity in the effectiveness of the solvent extracts against Gram-positive and Gram-negative bacteria may be due in part to the difference in morphological composition 
of the cells of these organisms, i.e. presence of an outer membrane which covers the cytoplasmic membrane before the peptidoglycan layer, in contrast to the thick peptidoglycan layer on the cell wall of a Gram-positive bacteria (Nikaido, 2003; Wendakoon and Gagnon, 2012).

As to the solvent extracts in general, the most appreciable antimicrobial activity was presented by alcoholic extracts, while distilled water extract exhibited a less interesting activity, with smaller inhibition zone against the test pathogens. However, in contrary to the present finding, other researchers like Yesmin $e t$ al. (2008) and Mainasara et al. (2011) have stated that water extracts of parts of C. procera (leaves, flower and fruit) have reported significant activity against both Gram-positive and Gram-negative strains of bacteria. The overall difference in activities of different solvent extracts of $C$. procera used in the study and those previously used by various researchers may be due to the difference in extract compounds. This suggestion was also inferred by Nanasombat (2005).

Variations in the antimicrobial activity of the studied solvents extracts of $C$. procera might be attributed to the high polarity of alcoholic solvents which enhanced their solubility and enabled them to naturally extract higher quantities of metabolites. Among the alcoholic extracts, broader spectrum and highest inhibitory activity were observed with extracts of the mixture of solvents against the test organisms as compared to individual alcoholic solvent. This may be a result of better solubility and improved polarity of the mixed solvents and thus a synergistic extraction of polar and non-polar compounds from the studied plant. Of utmost relevance is the report of Shobowale et al. (2015), that noted the solubility and relative polarities of solvents affect the activities of solvent extracts on microbial growth.

\section{Conclusions}

The hereby study provided information on the use of appropriate menstruum in the recovery of abundant secondary metabolites from leaves of $C$. procera. It is also of relevance in the search for alternative chemotherapy, as the study revealed a broad spectrum of action by the extracts obtained from $C$. procera leaves against selected pathogens that are responsible for some infectious diseases, suggesting therefore that the leaves of $C$. procera could be useful solely or as part of preparations of chemotherapeutic agents. However, despite the in vitro activity of the solvent extracts tested, such activity may not be translated in vivo, hence, the need to further investigate the in vivo activities of the solvent extracts of leaves of C. procera.

\section{Acknowledgements}

There was no external funding for this research. However, the authors appreciate Mr. Bolu of the Herbarium of the Department of Plant Biology, University of Ilorin, Ilorin, Nigeria, for identifying and authenticating the plant.

\section{Conflict of Interests}

The authors declare that there are no conflicts of interest related to this article. 


\section{References}

Ahmadizadeh C, Monadi A, Rezaie A, Rad MG, Jafari B (2018). Antibacterial activity of methanolic extract and essence of Sagebrush (Artemisia vulgaris) against pathogenic bacteria. Life Science Journal 15(5):69-73.

Akujobi C, Anyanwu BN, Onyeze C, Ibekwe VI (2004). Antibacterial activities and preliminary phytochemical screening of four medicinal plants. Journal of Applied Sciences 7(3):4328-4338.

Aliyu BS (2006). Common ethnomedicinal plants of the semi-arid regions of West Africa - Their descriptions and phytochemicals. Triumph publishing company limited, Gidan Sa'adu Zungur, Kano, Nigeria pp 93-94.

Amit K, Khairnar S, Bhamare R, Bhamare HP (2012). Calotropis procera: An ethnopharmacological update. Advanced Research in Pharmaceuticals and Biology 2:2250-0774.

Ashwari K (2009). Productivity of Calotropis procera and its use in renewable energy. Science Blogging. http://www.scientificblogging.com.

Asuzu IU, Onu OU (1994). Anthelmintic activity of the ethanolic extract of Piliostigma thonningii bark in Ascaridia galli infected chickens. Fitoterapia 65:291-294.

Behl PN, Luthra A (2002). Bullous eruption with Calotropis procera - a medicinal plant used in India. The Indian Journal of Dermatology, Venereology and Leprology 68(3):150.

Chundattu SJ, Agrawal VK, Ganesh N (2012). Phytochemical investigation of Calotropis procera. Arab Journal of Chemistry 9:230-234.

Clinical and Laboratory Standards Institute (CLSI) (2008). Performance standards for antimicrobialdisk and dilution susceptibility tests for bacteria isolated from animals, 3rd ed. Approved Standard M31-A3. USA.

Cowan MM (1999). Plant products as antimicrobial agents. Clinical Microbiology Reviews 12(4):564-582.

Crothers M, Newbound S (1998). Rubber bush (Calotropis procera). Agnote No. 551, Agdex 43. Northern Territory of Australia, Australia.

Dalitha MK (2008). Manual on the antimicrobial susceptibility testing. Indian Association of Medical Microbiologists pp 10-21.

Djeussi DE, Noumedem JA, Seukep JA, Fankam AG, Voukeng IK, Tankeo SB, ... Kuete V (2013). Antibacterial activities of selected edible plants extract against multidrug-resistant Gram-negative bacteria. BMC Complementary and Alternative Medicine 13(1):164.

Duraipandiyan V, Ayyanar M, Ignacimuthu S (2006). Antimicrobial activity of some ethnomedicinal plants used by Paliyar tribe from Tamil Nadu, India. BMC Complementary and Alternative Medicine 6(1):35.

Eloff JN (2004). Quantification the bioactivity of plant extracts during screening and bioassay guided fractionation. Phytomedicine 11:370-371.

Farnsworth NR (1996). Biological and phytochemical screening of plants. Journal of Pharmaceutical Sciences 55:225276.

Farouk A, Ahamed NT, AlZahrani O, Alamer KH, Bahobail A (2016). Antimicrobial activities evaluation from the extracts of leaves, flowers, fruits and latex of Calotropis procera from Taif. International Journal of Current Microbiology and Applied Sciences 5(11):240-256.

Gajare SM, Patil MV, Mahajan RT (2012). Phytochemical screening and antimicrobial activity of ethanol extract of Calotropis procera root. International Journal of Research in Phytochemistry and Pharmacology 2(3):143-146.

Gatsing D, Nkeugoauapi CFN, Nkah BFN, Kuiate JR, Tchouanguep FM (2010). Antibacterial activity, bioavailability and acute toxicity evaluation of the leaf extract of Alchornea cordifolia (Euphorbiaceae). International Journal of Pharmacology 6(3):173-182.

Gurudeeban S, Rajamanickam E, Ramanathan T, Satyavani K (2010). Antimicrobial activity of Citrullus colocynthis in Gulf of Mannar. International Journal of Current Research 2:078-081.

Harborne JB (1984). Phytochemical methods, a guide to modern technique of plant analysis, 2nd ed. Chapman and Hall, London pp 282-311.

Hooper DC (2001). Mechanisms of action of antimicrobials: focus on fuoroquinolones. Clinical Infectious Diseases 32(1):9-15.

Kareem SO, Akpan I, Ojo OP (2008). Antimicrobial activities of Calotropis procera on selected pathogenic microorganisms. African Journal of Biomedical Research 11:105-110.

Kuta FA (2008). Antifungal effects of $C$. procera stem back on Epidermophyton flocossum and Trichophyton gypseum. African Journal of Biotechnology 7(13):2116-2118. 
Levison ME (2004). Pharmacodynamics of antimicrobial drugs. Infectious Diseases Clinics of North America 18:451465.

Little EL Jr, Woodbury RO, Wadsworth FH (1974). Trees of Puerto Rico and the Virgin Islands. 2nd Vol. Ag. Handbook 449. Washington DC, USA:USDA.

Mainasara MM, Aliero BL, Aliero AA, Dahiru SS (2011). Phytochemical and antibacterial properties of Calotropisprocera (Ait) R. Br. (Sodom apple) fruit and bark extracts. International Journal of Modern Botany 1(1):8-11.

Meena AK, Yadav AK, Niranjan US, Singh B, Nagariya AK, Sharma K, ... Rao MM (2010). A review on Calotropis procera linn and its ethnobotany, phytochemical, pharmacological profile. Drug Invention Today 2:185-190.

Morsy N, Al Sherif EA, Abdel-Rassol TMA (2016). Phytochemical analysis of Calotropis procera with antimicrobial investigation. Main Group Chemistry 15(3):267-273.

Moshi MJ, Mbwambo ZH, Kapingu MC, Mhozya VH, Marwa C (2006). Antimicrobial and brine shrimp lethality of extracts of Terminalia mollis Laws. African Journal of Complementary and Alternative Medicine 3(3):59-69.

Murti Y, Yogi B, Pathak D (2010). Pharmacognostic standardization of leaves of Calotropis procera (Ait.) R. Br. (Asclepiadaceae). International Journal of Ayurveda Research 1:14-17.

Nanasombat S, Lohasupthawee P (2005). Antibacterial activity of crude ethanolic extracts and essential oils of spices against salmonellae and other enterobacteria. KMITL Science and Technology Journal 5(3):527-538.

Nenaah G (2013). Antimicrobial activity of Calotropis procera ait. (Asclepiadaceae) and isolation of four flavonoid glycosides as the active constituents. World Journal of Microbiology and Biotechnology 29(7):1255-1262.

Nikaido H (2003). Molecular basis of bacterial outer membrane permeability revisited. Microbiology and Molecular Biology Reviews 67(4):593-656.

Obeidat M, Shatnawi M, Al-alawi M, Al-Zu’bi E, Al-Dmoor H, Al-Qudah M, ... Ismael O (2012). Antimicrobial activity of crude extracts of some plant leaves. Research Journal of Microbiology 7(1):59-67.

Ochei J, Kolhatkar A (2008). Medical Laboratory Science, Theory and Practices, Tata McGraw-Hill pp 273-277.

Ogueke CC, Ogbulie JN, Okoli IC, Anyanwu BN (2007). Activities and toxicological potentials of crude ethanolic extracts of Euphorbia hirta. Journal of American Science 3(3):11-6.

Osadebe PO, Ukwueze SE (2004). A comparative study of the phytochemical and antimicrobial properties of the Eastern Nigeria species of African mistletoe (Loranthus micranthus) sourced from different host frees. Journal of Biological Research and Biotechnology 2(1):18-23.

Pavithra PS, Janani VS, Charumathi KH, Indumathy R, Potala S, Verma RS (2010). Antibacterial activity of the plant used in Indian herbal medicine. International Journal of Green Pharmacy 10:22-28.

Shobowale OO, Ogbulie NJ, Itoandon EE, Oresegun MO, Olatope SOA (2015). Phytochemical and antimicrobial evaluation of aqueous and organic extracts of Calotropisprocera Ait. leaf and latex. Nigerian Food Journal 31(1):7782.

Silva MCC, Silva AB, Teixeira FM, Sousa PCP, Rondon RMM, Junior JRH, ... de Vasconcelos SMM (2010). Therapeutic and biological activities of Calotropis procera (Ait.) R.Br. Asian Pacific Journal of Tropical Medicine 3(4):332-336.

Valgas C, Souza SM, Smania EFA, Smania Jr. A (2007). Screening method to determine antibacterial activity of natural products. Brazilian Journal of Microbiology 38:369-380.

Van Der Watt E, Pretorius JC (2001). Purification and identification of active antibacterial components in Carpobrotus edulis L. Journal of Ethnopharmacology 76(1):87-91.

Verma R, Satsangi GP, Shrivastava JN (2010). Ethno-medicinal profile of different plant parts of Calotropis procera (Ait.) R. Br. Ethnobotanical Leaflets 14:721-742.

Wendakoon C, Gagnon D (2012). Evaluation of selected medicinal plants extracted in different ethanol concentrations for antibacterial activity against human pathogens. Journal of Medicinally Active Plants 1(2):60-68.

Yesmin MN, Uddin NS, Sanzida M, Muhammad AA (2008). Antioxidant and antibacterial activities of Calotropis procera. American-Eurasian Journal of Agricultural and Environmental Sciences 4(5):550-553. 
Falana MB and Nurudeen QO (2020). Not Sci Biol 12(2):208-221

OPEN ACCESS

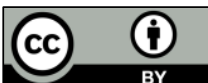

The journal offers free, immediate, and unrestricted access to peer-reviewed research and scholarly work. Users are allowed to read, download, copy, distribute, print, search, or link to the full texts of the articles, or use them for any other lawful purpose, without asking prior permission from the publisher or the author.

License - Articles published in Notulae Scientia Biologicae are Open-Access, distributed under the terms and conditions of the Creative Commons Attribution (CC BY 4.0) License.

(C) Articles by the authors; SHST, Cluj-Napoca, Romania. The journal allows the author(s) to hold the copyright/to retain publishing rights without restriction. 